\title{
Sweetclover Production and Use in Florida ${ }^{1}$
}

\section{G. Chambliss ${ }^{2}$}

Hubam Sweetclover can be grown in Florida. It is an annual white sweetclover with the scientific name Melilotus alba (Figure 1). Another variety, Floranna, has been grown, but seed are no longer available. Sweetclover is not a true clover as is white, red, or crimson clover (Trifolium sp.), and is placed in an entirely different genus or group. It is more closely related to alfalfa and when seed are inoculated at planting, an alfalfa - sweetclover inoculant must be used. There are biennial types of sweetclover grown in the U. S., but not in Florida. Volunteer plants of an annual yellow flowered type (Melilotus officinalis) can occasionally be seen in Florida. Leaves of sweetclover have three leaflets that tend to be toothed around the margins. Sweetclover develops an extensive root system with a deep taproot. Once established it is able to grow under somewhat dryer soil conditions than true clovers.

\section{Site-Soil Adaptation}

Sweetclover can be grown throughout Florida on many different soils. It can grow under wet conditions as long as flooding does not occur and on dry soils if enough moisture is available for germination and the development of a good root system. Clay soils or soils underlaid with clay are

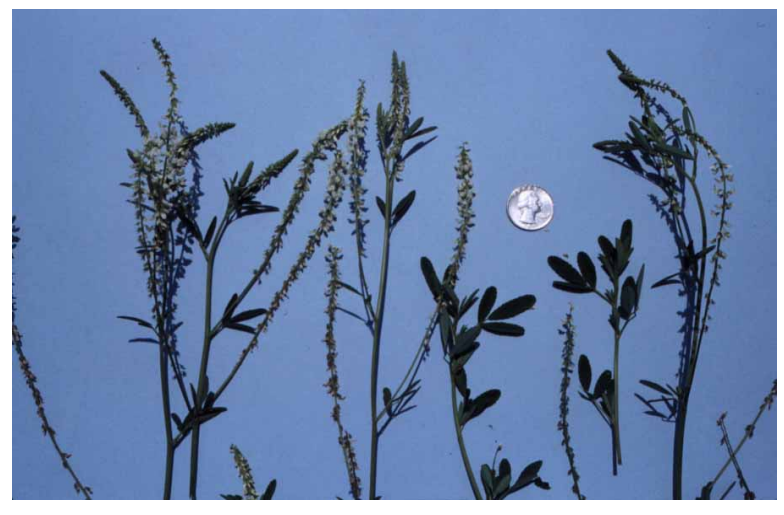

Figure 1. Annual White Sweetclover

best for sweetclover, but it can also be grown successfully on flatwoods.

\section{Liming and Fertilization}

Soils should be limed to a $\mathrm{pH}$ of 6.5. Since sweetclover is planted in the fall, this will require advance planning with soil testing and liming in the previous spring or summer. Many flatwood soils have a $\mathrm{pH}$ of 4.5 to 5.5 and will require up to two tons of limestone per acre to raise the $\mathrm{pH}$ to 6.5 .

Limestone may be needed every 4 to 5 years to maintain a suitable $\mathrm{pH}$ for growing sweet clover. Follow soil test recommendations for phosphorus and potassium fertilization. Sixty pounds of $\mathrm{P}_{2} \mathrm{O}_{5}$ and

1. This document is SS-AGR-189, one of a series of the Agronomy Department, Florida Cooperative Extension Service, Institute of Food and Agricultural Sciences, University of Florida. Published February 2003. Visit the EDIS Web Site at http://edis.ifas.ufl.edu.

2. C. G. Chambliss, associate professor, Agronomy Department, Florida Cooperative Extension Service, Institute of Food and Agricultural Sciences, University of Florida, Gainesville, FL. 32611. 
120 pounds of $\mathrm{K}_{2} \mathrm{O}$ may be required. Apply at planting or shortly after seedlings emerge.

\section{Planting}

Plant sweet clover in the fall between October 15 and November 15. Broadcast 12 to 15 pounds of inoculated seed per acre. If a precision planter such as a drill is used, the seeding rate can be lowered to 8 to 10 pounds per acre. Seed should be planted no deeper than $1 / 4$ to $1 / 2$ inch deep. Inoculant (nitrogen fixing bacteria) should be applied at three times the rate recommended by the manufacturer to ensure good nodulation. Use a commercial sticker or syrup (mixed with water) to stick the inoculant to the seed. Buy the sticker when you buy the inoculant. If too much sticker is applied, the seed may need to be dried so that they will flow through the planting equipment. Dry on a tarp in the shade. Direct sunlight will kill the nitrogen-fixing bacteria in the inoculant. Another option is to add something to the seed, such as cottonseed meal or a similar material,to absorb the excess moisture. Plant on a well-prepared, moist, and firmed seedbed or on a closely grazed pasture sod. A cultipacker type seeder, cyclone seeder, or conventional grain drill with small seed box attachment can be used on the prepared seedbed. On a pasture sod, use a "pasture drill" or a broadcast seeder and a drag or a light disc plus a roller if available. Volunteer stands of sweetclover may occur if sufficient seed shattered and fell to the ground in the previous season. In October, the pasture grass should be grazed short in order to allow the volunteer seedlings to establish.

\section{Use}

Grazing - Sweetclover is used mainly for grazing (Figures 2 and 3). It is usually ready to graze in February and if grazed continuously (not allowed to flower and make seed) it will stay green and make new growth until June. Under these conditions it may be necessary to reseed in the fall for the next season's crop. Cattle may be reluctant to graze sweetclover when they first enter the pasture, but quickly become accustomed to it. Sweetclover may produce as much as 2 to $21 / 2$ tons of dry matter per acre. With rotational grazing animals may utilize from 60 to 70 percent of the production. Forage quality is high with protein greater than $15 \%$ and digestibility greater than $60 \%$ (similar to alfalfa). Cattle of all classes should make excellent gains when grazing sweetclover. Bloat is a possibility, and producers should watch animals closely when grazing sweetclover.

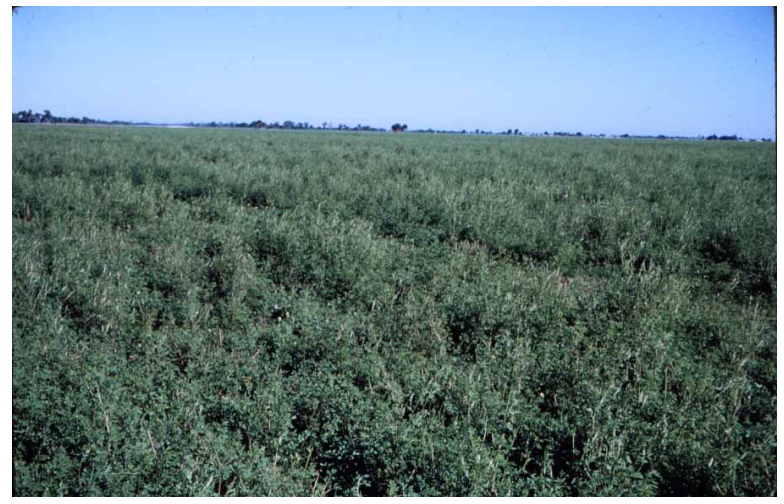

Figure 2. Excellent field of sweetclover, Okeechobee County.

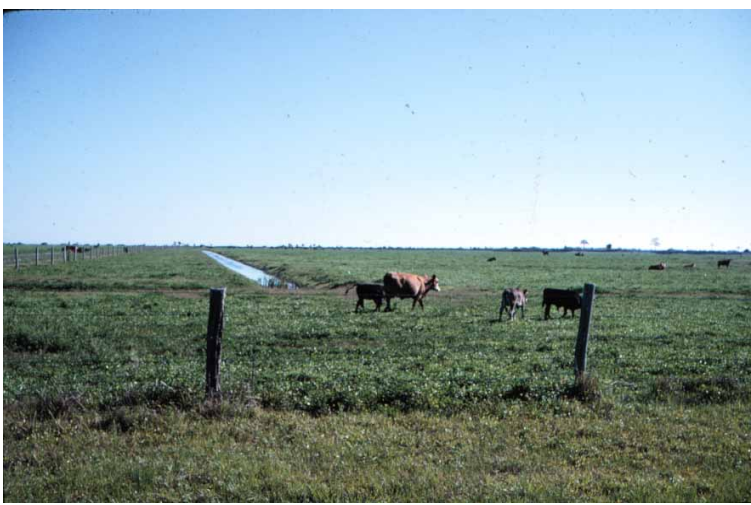

Figure 3. Cattle grazing irrigated sweetclover, Okeechobee County.

Hay - Sweetclover should not be harvested for hay or silage in Florida because it contains a chemical compound called coumarin which, when sweetclover hay molds, converts to dicoumarol. Dicoumarol, a compound commonly used in rat poison, causes internal bleeding in livestock.

Seed Production - Most commercial seed production is done in Texas and other western states. Very little if any seed are harvested in Florida, although seed can be produced here. Sweetclover usually starts flowering in early April and will mature a seed crop in May. Cattle must be removed in early April or grazing restricted in order to make a seed crop. Sweetclover has a long flowering period (indeterminate growth habit) and both mature and green seed will be harvested. Seed yields of 100 to 
500 pounds per acre have been reported. Honey bees will work sweet clover for nectar and pollen when it is flowering and this will help increase the seed crop.

Green Manure - Sweetclover was used as a green manure and cover crop in the past, but with the advent of cheap nitrogen fertilizer this use has declined. If plowed under in March it will stimulate growth of the following crop. Also, in pastures some extra nitrogen is left for the grass to use as the clover disappears. Do not use sweetclover as a cover crop on land planted to winter or spring vegetables since sweetclover produces hard seed that can remain in the soil for many years and volunteer in future crops.

\section{Pest Problems (Diseases, Insects, Nematodes, and Weeds)}

Under certain conditions there are three different diseases that may affect sweetclover: root rot, black stem and stem canker. The major insect pest of sweetclover is the adult sweetclover weevil. Other insect pests include the sweetclover root borer, the sweetclover aphid, and blister beetles. Several nematodes have been found on sweetclover but are not usually a problem.

Winter weeds are not likely to be a problem where sweetclover is overseeded on permanent grass pastures, but could be a problem on clean-tilled seedbeds. No particular weed control herbicides are recommended.

\section{Summary}

Sweetclover is adapted to a wider range of soil and moisture conditions than the true clovers.

- It is found growing along roadsides, railroad tracts, and other places throughout Florida.

- It is not tolerant of acid soils but can be grown on high $\mathrm{pH}$ soils.

- Recommended soil $\mathrm{pH}$ for growing Sweetclover is 6.5.

- It requires a high level of fertility (P and $\mathrm{K})$ for high production.
- It returns relatively large amounts of nitrogen to the soil when grown as a green manure crop.

- Cattle make good weight gain when grazing it.

- It can be grazed from February through May.

- Honey bees pollinate sweetclover - increasing seed production, and collect nectar to produce honey.

Sweetclover is not used to any great extent in Florida at the present time. Cool season grasses plus nitrogen fertilizer are easy to manage and have gained in popularity for use as winter/spring pasture. If the cost of nitrogen fertilizer increases, there may be renewed interest in using sweetclover. 